\title{
Community Structure and Composition of Social Wasps (Hymenoptera: Vespidae) in Different Vegetation Types in São Paulo, Brazil
}

\author{
MA Clemente ${ }^{1}$, R Guevara ${ }^{2}$, HR Moleiro ${ }^{1}$, Ot Silveira ${ }^{3}$, E Giannott ${ }^{1}$ \\ 1 - Departamento de Zoologia, Instituto de Biociências, Universidade Estadual Paulista Júlio de Mesquita Filho, Rio Claro, Brazil \\ 2 - Red de Biología Evolutiva, Instituto de Ecología AC, INECOL, Xalapa, Mexico \\ 3 - Campus de Pesquisas, Museu Paraense Emílio Goeldi, Belém, Brazil
}

\section{Article History}

\section{Edited by}

Gilberto M. M. Santos, UEFS, Brazil

Received 24 May 2020

Initial acceptance 20 July 2020

Final acceptance 20 August 2020

Publication date 30 September, 2020

\section{Keywords}

Vespidae; biodiversity; species richness; inventory.

\section{Corresponding author}

Mateus Aparecido Clemente

Departamento de Zoologia

Instituto de Biociências

Universidade Estadual Paulista Júlio de

Mesquita Filho

Av. 24 A, no 1515, CEP: 13506-752

Bela Vista, Rio Claro, São Paulo, Brasil.

E-Mail: mateus1981@gmail.com

\begin{abstract}
Social wasps participate in food webs, act as biological control agents in small crops and the natural environment, and act as potential pollinators. The objective of this study was to carry out an inventory of social wasps in five phytophysiognomies with different degrees of anthropogenic disturbance in São Paulo, Brazil. The collections were performed by active search and attractive traps to survey social wasps. We collected wasp for one year with collection campaigns every other month totaling six campaigns for site. We collected a total of 913 individuals representing 31 species and eight genera. The species with the highest abundances were Agelaia pallipes and Agelaia vicina. The highest richness of social wasps was found in the riparian forest and regenerating Cerrado. We conclude that social wasp richness and diversity varies according to habitat vegetation characteristics and that these effects are likely mediated by resulting differences in the provision of resources and nesting locations among the different environments. The areas in this study have suffered considerable vegetation loss due to common farming practices, however, the existing fragments are still capable of hosting a rich social wasp fauna.
\end{abstract}

\section{Introduction}

The Vespidae family contains six subfamilies including both solitary (Masarinae, Eumeninae and Euparagiinae) and eusocial species (Stenogastrinae, Vespinae and Polistinae). Polistinae is a prominent group with more than 900 species and wide geographical distribution, especially in the Neotropics (Carpenter \& Marques, 2001).

Some social wasps have a high relative abundance (Carpenter \& Marques, 2001) and act as main predators regulating preys populations (Santos et al., 2007) including various agricultural pests, therefore functioning as biological control agents in crops (Prezoto, 1999; Carpenter \& Marques, 2001). Also, these wasps are frequent floral visitors, where they collect nectar and act as potential pollinators of several plant species (Clemente et al., 2012).
In the last decade there has been an expressive growth in the number of studies, with the objective of knowing the distribution and diversity of social wasps in different biomes in Brazil. Barbosa et al. (2016) condensed 78 publications including inventories of social wasps for Brazil and noted that the information was concentrated in three States, Minas Gerais, São Paulo and Bahia which together comprised over half of the studies.

In the last decade, innumerable surveys of social wasps have been conducted in São Paulo state. These studies were conducted in various vegetation types and have greatly enriched our knowledge of these insects. However, knowledge of species in southeastern Brazil remains inadequate, especially in biome convergence areas, which are expected to have high biodiversity.

We conducted a survey of social wasps in five different vegetation types of central-eastern São Paulo, comparing the 
abundance and species richness as a function of vegetation type. We measured the effect of environmental variables (temperature, relative humidity, and rainfall) on wasp richness and abundance throughout the study period. We also assessed wasp distribution in different periods of the year (hot-humid and cold-dry) and analyzed the faunal similarity between sampling areas.

\section{Materials and Methods}

Study areas

(1) The site with the lowest anthropogenic impact was a semideciduous forest fragment (FSD) (Pagano \& Leitão Filho, 1987), covering parts of the municipalities of Rio Claro and Araras, SP (22 $\left.21^{\prime} 06^{\prime \prime} \mathrm{S}, 47^{\circ} 29^{\prime} 07^{\prime \prime} \mathrm{W}\right)$. The area has a more or less dense canopy due to the different degrees of disturbance, such as the advance of sugar cane monoculture, fires, and deforestation. The tree component is presented in two floristically distinct strata, where the upper stratum, which is defined between seven and 15 meters in height, in addition to emerging strata reaching $20-25 \mathrm{~m}$, is more diverse (Pagano et al., 1987) (Table 1).

(2) The site with the second-lowest anthropogenic impact was a Cerradão area (C) (22 $\left.24^{\prime} 49^{\prime \prime} \mathrm{S}, 47^{\circ} 45^{\prime} 32^{\prime \prime} \mathrm{W}\right)$, located in the municipality of Ipeúna, SP, which presents itself physiognomically as a forest with some similarities to a Savanna in a restricted sense. This area has a continuous canopy and tree cover between $50 \%$ and $90 \%$, which directly influences the light conditions, favoring differentiation in the shrub and herbaceous strata. However, in its surroundings, there are extensive areas of sugar cane plantations, which generates strong negative pressure on the fragment and fires, a common practice in the pre-harvest. Additionally, there is intense traffic of motorcycles inside the forest, causing strong damage to the soil and seedlings, where silting and numerous tree falls have been observed, contributing to the alteration of this ecosystem (Table 1).

(3) The site with the third-lowest anthropogenic impact was a riparian forest (RF) located in the municipality of Itirapina, next to the Lapa stream $\left(22^{\circ} 22^{\prime} 16^{\prime \prime} \mathrm{S}, 47^{\circ} 47^{\prime}\right.$ $\left.16^{\prime \prime} \mathrm{W}\right)$. The study area is strongly impacted by agricultural activities, which reduced it from the originally Mesophilic Semidecidual Forest to just one strip of Riparian Forest. In a large part of its course, Riparian Forest presents only a narrow strip surrounded by sugar cane (Silveira et al., 2008) (Table 1).

(4) The site with the highest anthropogenic impact was a regenerating Cerrado (RC) site is located in a municipal public area, which borders the south with the Universidade Estadual Paulista (UNESP) and the northeast with the State Forest Edmundo Navarro de Andrade (FEENA) (22 24' $22^{\prime \prime} \mathrm{S}, 47^{\circ} 32^{\prime} 18^{\prime \prime} \mathrm{W}$ ), a fragment of Swampy Forest and a neighborhood, which causes intense pressure from urban areas. This site has a forest aspect, absence of understory,
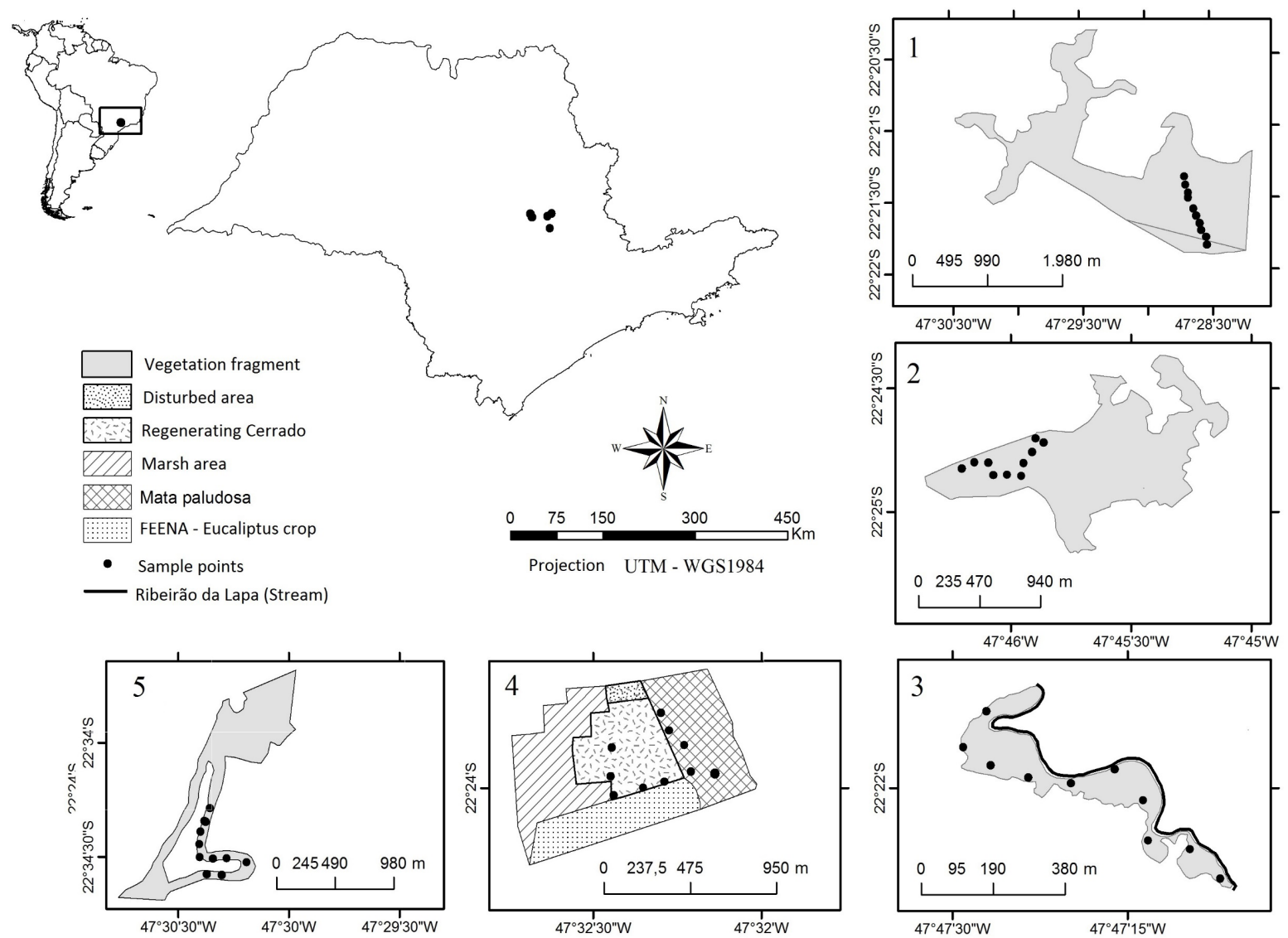

Fig 1. Map showing the distribution of the sampling sites and sampling points within each site. 1: Semideciduous forest; 2 : Cerradão; 3. Riparian forest; 4. Regenerating Cerrado; and 5. Restored forest. 
and trees of relatively uniform size. Plant litter is scarce or nonexistent, neither are seedlings observed (Cardoso-Leite et al., 2004) (Table 1).

(5) The site with the second-highest anthropogenic impact was a restored forest area (RTF) $\left(22^{\circ} 34^{\prime} 34^{\prime \prime} \mathrm{S}, 47^{\circ} 30^{\prime}\right.$
25 " W). Its restoration and planting process started in 1987, making 28 years for the present study. The area is surrounded by sugar cane fields. Its vegetation, in general, is of exotic plants and with a medium canopy of approximately $10 \mathrm{~m}$ high (Vieira \& Gandolfi, 2006) (Table 1).

Table 1. Characterization of different physiognomies in the east central of São Paulo according to the degree of anthropic impact. 1 - Less anthropic impact; 5 - More anthropic impact; AV: Arboreal Vegetation; SGE: Soil Groove and Erosion; NS500: Number of 500m sections.

\begin{tabular}{|c|c|c|c|c|c|}
\hline \multirow{3}{*}{ Fragment characteristics } & \multicolumn{5}{|c|}{ Degree of anthropogenic impact } \\
\hline & 1 & 2 & 3 & 4 & 5 \\
\hline & Semideciduous forest & Cerradão & Riparian forest & Restored forest & $\begin{array}{c}\text { Regenerating } \\
\text { Cerrado }\end{array}$ \\
\hline Size $\left(m^{2}\right)$ & 230,000 & $1,140,710$ & $14,000,000$ & 200,000 & 100 \\
\hline $\begin{array}{l}\text { Presence of lentic and lotic } \\
\text { water courses }\end{array}$ & - & + & + & + & + \\
\hline $\begin{array}{l}\text { Agricultural activity in the } \\
\text { surroundings }\end{array}$ & + & + & + & + & + \\
\hline Agricultural activity inside & - & - & + & + & + \\
\hline SGE & - & + & + & + & + \\
\hline NS500 & + & + & + & - & - \\
\hline Conservation level & $\begin{array}{l}\text { Secondary forest } \\
\text { in intermediate } \\
\text { stage of regeneration }\end{array}$ & $\begin{array}{c}\text { Secondary forest } \\
\text { in intermediate } \\
\text { stage of regeneration }\end{array}$ & $\begin{array}{l}\text { Secondary forest } \\
\text { in intermediate } \\
\text { stage of regeneration }\end{array}$ & $\begin{array}{l}\text { Intermediate stage } \\
\text { of restoration }\end{array}$ & $\begin{array}{l}\text { Regenerating } \\
\text { Cerrado }\end{array}$ \\
\hline Reference & $\begin{array}{l}\text { Pagano \& Leitão } \\
\text { Filho, } 1987\end{array}$ & Author information & Fragoso, 2005 & Siqueira, 2002 & $\begin{array}{c}\text { Cardoso-Leite } \\
\text { et al., } 2004\end{array}$ \\
\hline
\end{tabular}

Sampling design

According to data from other surveys, most social wasps collected by attractive traps are from the Epiponini tribe (Souza \& Prezoto, 2006; Locher et al., 2014). Using this information and the literature review by Cruz et al. (2006), we estimated the average radius of the activity zone of these species in $93.75 \mathrm{~m}$ (standard deviation $=56.04$ ). Therefore, at each site we set 10 sampling stations at a distance of no less than $100 \mathrm{~m}$ among them. Each site we sample every other month for a whole year totaling six sampling campaigns at each site. The actual sampling period varied from site to site. Overall, our sampling campaigns extended from October 2011 to July 2013. Sampling in the Cerradão was conducted from October 2011 up to August 2012, in the riparian forest was from November 2011 to September 2012, in the restored forest from August 2012 to June 2013, and in the regenerating Cerrado and semideciduous forest from September 2012 to July 2013. In every sampling campaign at each site, wasps were collected by means of attractive traps and active search.
Attractive traps

We set an attractive trap in each of the 10-sampling station in each site and the traps were active for seven days. Five of the ten traps at each site were placed at about $1.5 \mathrm{~m}$ height and another five were placed in the canopy (about 5-9 $\mathrm{m}$ height). The traps consisted of $2 \mathrm{~L}$ PET bottles with four drilled holes (diameter $\sim 3 \mathrm{~cm}$ ) in the top third of the bottle and contained $200 \mathrm{ml}$ of concentrated passion fruit juice as an attractive (Souza \& Prezoto, 2006). The trap design was modified according to Santos (1996) and has been routinely used for social wasp surveys in Brazil (Souza \& Prezoto, 2006; Locher et al., 2014).

\section{Active search}

Wasps were actively searched along the $1 \mathrm{~km}$ trails where attractive traps were installed. Tree cavities, broadleaf trees, and buildings were surveyed, and wasps were collected using a sweep net. The trail were walked twice during every sampling campaign from 09:00 to $16: 00 \mathrm{~h}$ that corresponds 
with the period with the highest activity of the social wasps (Souza \& Prezoto, 2006). The first walk was conducted the day the traps were set, and seven days later when the traps were withdrawn, we walked the transects and actively searching for wasps. Because of that, we accumulated a total of 84 collection hours per area ( $7 \mathrm{~h}$ search $\mathrm{x} 2$ walks $\mathrm{x} 6$ campaigns). To kill the collected insects we used death chambers loaded with ether, and then they were put in $70 \%$ ethanol. All data collected through the active search were added to the data collected with traps.

\section{Environmental variables}

Relative humidity and air temperature were measured at each point during installation and removal of traps using a digital thermohygrometer. Also, mean temperature, relative humidity and monthly rainfall data were obtained from the Analysis and Environmental Planning Center Station (CEAPLA) at UNESP, in Rio Claro, which is located approximately 20-50 $\mathrm{km}$ from the sampling areas.

\section{Identification and specimen placement}

Specimens were sorted and identified at the Zoology Department at the Biosciences Institute of UNESP, using genus and species identification keys (Richards, 1978; Carpenter \& Marques, 2001; Pickett \& Wenzel, 2007; Andena \& Carpenter, 2014), and by comparison with specimens from the Zoology Department social wasp collection.

\section{Data analysis}

PAST version 1.49 (Hammer et al., 2001), BioEstat version 5.0 (Ayres et al., 2007) and R version 2.15 (R Core Team, 2012) were used for statistical analyses.

For phytophysiognomy we calculated the ShannonWiener diversity index (H’) (Krebs, 1998). For the evaluation of species constancy among monthly collections per study area, we used the formula proposed by Bodenheimer (1955) as modified by Silveira Neto et al. (1976) Constancy $_{i}(\%)=\frac{p_{i}}{N} 100$ , where $P_{i}=$ number of collections where the $i$ species was observed and $N=$ total number of collections. Based on the constancy value, the species were classified as (1) constant species (constancy $\geq 50 \%$ ); (2) accessory species (present between $25 \% \leq$ constancy $<50 \%$ of samples); (3) adventitious species (constancy $<25 \%$ ).

To test for significant differences in wasp abundance and richness among study areas, we used a mixed-effects model, lme function in the nlme package in R (Pinheiro et al., 2012) with restricted maximum likelihood (REML). Vegetation type (sites) was defined as a fixed factor and sampling points with each site were defined as a random factor. To comply with model assumptions on homoscedasticity and normality of the residuals we modeled the variance following a power function structure for a constant variance equal to one. Significance of the fixed factor was based on the marginal sum of squares to minimize bias in the results. We used contrasts based on the linear predictor of the model to detect significant differences among levels when the overall fixed factor had significant effects. To do this we used the function estimable in the gmodels package in $\mathrm{R}$ (Warnes et al., 2018).

We used the rarefaction method in $\mathrm{R}$ to test sampling sufficiency. According to this analysis, the estimated number of species in a sample of $\mathrm{N}$ individuals is the sum of the probabilities that each species is included in the sample. Sanders (1968) proposes this analytical solution to calculate the possible combinations of sample sizes for a community.

To evaluate the influence of environmental variables on the richness and abundance of social wasps among sites we used generalized mixed-effects models in $\mathrm{R}$ with the function glmer in the lme4 package (Bates et al., 2015). Site with five levels, one covariate (monthly rainfall, mean temperature and relative humidity, and weekly temperature and relative humidity) and their interaction thereof were fitted as explanatory elements in the model. Species richness and abundance of social wasp corresponded to monthly estimates. We set the random component of the model as the mean average given the sequence of sampling months. Richness data were fitted with a Poisson distribution and the logarithmic link function; abundance data were fitted following a Gaussian distribution with the logarithmic link function. Before fitting the models, we analyzed the correlation among environmental variables and fitted only those models that included noncorrelated environmental variables.

\section{Results}

\section{Social wasp diversity in east-central São Paulo}

We collected 31 species grouped in eight genera. Of the 913 individuals collected, $52 \%(n=477)$ were collected by active searches and $48 \%(n=436)$ was collected in traps. The Epiponini was the best represented tribe with $81.16 \%$ of the records. The Mischocyttarini and Polistini, were represented only by the $16.32 \%$, and $2.52 \%$ respectively. The species with the highest abundances were Agelaia pallipes (Olivier) $(32.6 \%, \mathrm{n}=298)$ and Agelaia vicina (Saussure) $(23.00 \%, \mathrm{n}=$ 210). After Agelaia species, Mischocyttarus montei (Zikán) $(6.35 \%, \mathrm{n}=58)$, Polybia chrysothorax (Lichtenstein) $(5.91 \%$, $\mathrm{n}=54)$, and Mischocyttarus rotundicollis (Cameron) $(4.93 \%$, $\mathrm{n}=45$ ) had the highest abundances (Table 2).

\section{Wasp richness and abundance among study sites}

The riparian forest site had the greatest species richness ( $\mathrm{S}=23$ ), followed by regenerating Cerrado $(\mathrm{S}=21)$. Relative abundance was highest in regenerating Cerrado followed by riparian forest. Epiponini species represented more than $80 \%$ of the total sample in all areas except for restored forest where Mischocyttarini species were more abundant ( $\sim 50 \%$ of the total sample; Table 2). 
Table 2. Abundance $(\mathrm{Ab})$ and relative frequency $(\mathrm{F} \%)$ of wasp species sampled in five study areas in east central São Paulo state. FSD: Semideciduous forest; C: Cerradão; RF: Riparian forest; RC: Regenerating Cerrado; RTF: Restored forest.

\begin{tabular}{|c|c|c|c|c|c|c|c|c|c|c|c|}
\hline \multirow{2}{*}{ Tribe } & \multicolumn{2}{|c|}{ FSD } & \multicolumn{2}{|c|}{$\mathbf{C}$} & \multicolumn{2}{|c|}{ RF } & \multicolumn{2}{|c|}{$\mathbf{R C}$} & \multicolumn{2}{|c|}{ RTF } & \multirow{2}{*}{$\begin{array}{c}\text { Total } \\
-\end{array}$} \\
\hline & $\mathrm{Ab}$ & $\mathrm{F} \%$ & $\mathrm{Ab}$ & $\mathrm{F} \%$ & $\mathrm{Ab}$ & $\mathrm{F} \%$ & $\mathrm{Ab}$ & $\mathrm{F} \%$ & $\mathrm{Ab}$ & $\mathrm{F} \%$ & \\
\hline \multicolumn{12}{|l|}{ Epiponini } \\
\hline Agelaia pallipes & 19 & 25.00 & 31 & 23.66 & 57 & 23.17 & 178 & 59.93 & 13 & 7.98 & 298 \\
\hline Agelaia vicina & 32 & 42.11 & 44 & 33.59 & 112 & 45.53 & 16 & 5.39 & 6 & 3.68 & 210 \\
\hline Apoica pallens & - & - & 1 & 0.76 & 3 & 1.22 & 2 & 0.67 & 3 & 1.84 & 9 \\
\hline Brachygastra lecheguana & - & - & - & - & 4 & 1.63 & - & - & - & - & 4 \\
\hline Polybia chrysothorax & - & - & 1 & 0.76 & 2 & 0.81 & 10 & 3.37 & 41 & 25.15 & 54 \\
\hline Polybia minarum & 2 & 2.63 & - & - & - & - & 1 & 0.34 & - & - & 3 \\
\hline Polybia occidentalis & - & - & 3 & 2.29 & 6 & 2.44 & 3 & 1.01 & - & - & 12 \\
\hline Polybia paulista & - & - & - & - & 2 & 0.81 & 5 & 1.68 & - & - & 7 \\
\hline Polybia sericea & - & - & - & - & - & - & 3 & 1.01 & - & - & 3 \\
\hline Polybia jurinei & 1 & 1.32 & 1 & 0.76 & - & - & 5 & 1.68 & 3 & 1.84 & 10 \\
\hline Protonectarina sylveirae & - & - & - & - & - & - & 1 & - & - & - & 1 \\
\hline Synoeca cyanea & - & - & 2 & 1.52 & 2 & 0.81 & 2 & 0.67 & - & - & 6 \\
\hline \multicolumn{12}{|l|}{ Mischocyttarini } \\
\hline Mischocyttarus paraguayensis & - & - & - & - & 1 & 0.41 & - & - & - & - & 1 \\
\hline Mischocyttarus ignotus & - & - & - & - & 1 & 0.41 & - & - & 3 & 1.84 & 4 \\
\hline Mischocyttarus tricolor & - & - & - & - & - & - & 2 & 0.67 & 3 & 1.84 & 5 \\
\hline Mischocyttarus montei & 1 & 1.32 & - & - & 1 & 0.41 & 2 & 0.67 & 54 & 33.13 & 58 \\
\hline Total Mischocyttarini & 4 & 5.26 & 21 & 16.03 & 21 & 8.54 & 16 & 5.39 & 87 & 53.37 & 149 \\
\hline \multicolumn{12}{|l|}{ Polistini } \\
\hline Polistes cinerascens & - & - & - & - & 3 & 1.22 & - & - & - & - & 3 \\
\hline Polistes billardieri & - & - & 1 & 0.76 & - & - & - & - & - & - & 1 \\
\hline Polistes lanio & 2 & 2.63 & - & - & - & - & 7 & 2.36 & 3 & 1.84 & 12 \\
\hline Polistes simillimus & - & - & - & - & 1 & 0.41 & - & - & - & - & 1 \\
\hline Polistes geminatus & - & - & - & - & 1 & 0.41 & - & - & - & - & 1 \\
\hline Polistes subsericius & - & - & - & - & 2 & 0.81 & - & - & - & - & 2 \\
\hline Polistes versicolor & - & - & 2 & 1.52 & 1 & 0.41 & - & - & - & - & 3 \\
\hline Total Polistini & 2 & 2.63 & 3 & 2.28 & 8 & 3.25 & 7 & 2.36 & 3 & 1.84 & 23 \\
\hline Total individuals & 76 & & 131 & & 246 & & 297 & & 163 & & 913 \\
\hline
\end{tabular}


The mixed effects model revealed significant differences in the local abundance among vegetation types $(F=21.7 ; d$. $f .=4,36 ; p<0.0001)$. Regenerating Cerrado and riparian forest had similar abundances $(t=1.2 ; d . f .=36 ; p=0.2394)$ and were significantly higher than those of the other three vegetation types $(t>2.47 ;$ d. $f .=36 ; p<0.0185)$. Nonetheless, the abundance in three low abundance vegetation types (Cerradão, semideciduous forest and restored forest) differed significantly among all paired comparisons $(t=2.3 ; d . f .=36$; $p<0.0284)$; of all these three sites, the semideciduous forest had the lowest abundance while the restored forest showed the highest abundance (Fig 2).

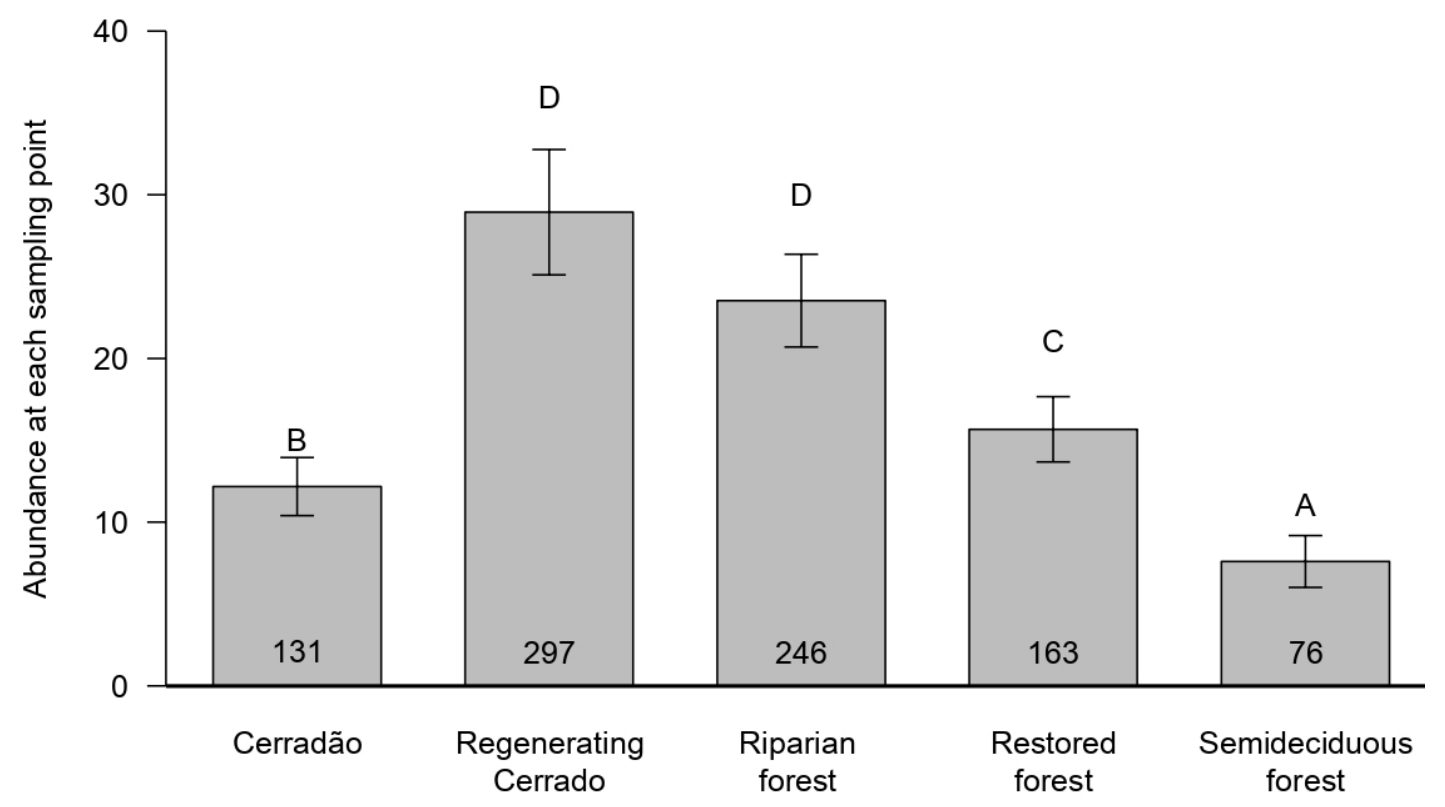

Fig 2. Abundance of social wasps collected for each point in each type of vegetation. The number inside the bars indicates a total abundance for each vegetation. Different capital letters represent significant differences.

Also, species richness was highest in regenerating Cerrado and riparian forest averaging almost eight species at each sampling point that added up to 21 and 23 species respectively $(t=2.52 ; d . f .=36 ; p=0.0164)$, and there was no significant difference between these two vegetation types $(t=$ $0.42 ;$ d. $f .=36 ; p=0.6823)$. Also, the semideciduous forest had the lowest species richness, on average less than four species in each sampling points that added up to 12 species, and this was significantly different from the Cerradão and restored forest that averaged almost six species at each point and added up to 14 and 15 species respectively $(t>2.9 ; d . f$. $=$ 36; $p<0.0066$ ) (Fig 3).

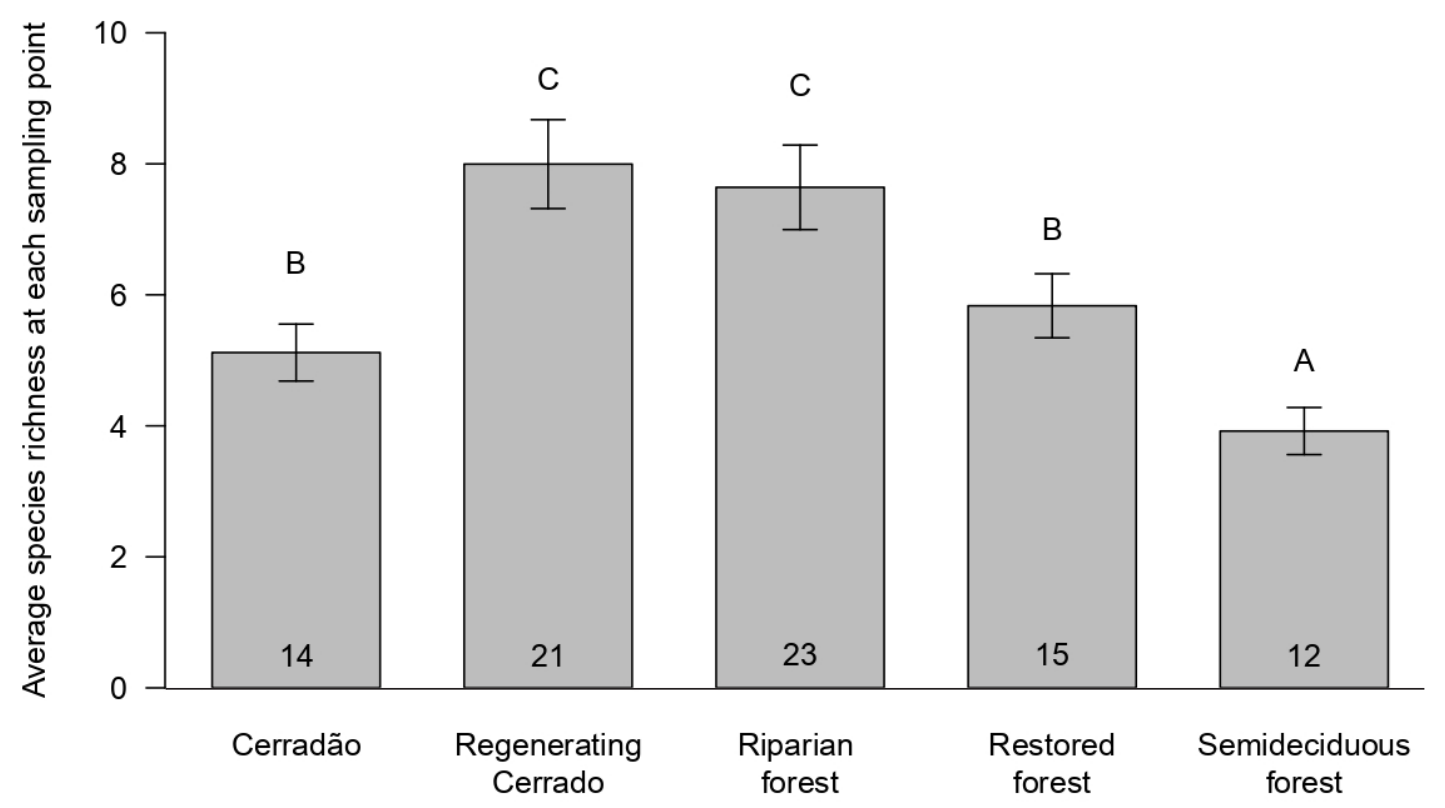

Fig 3. Species richness of social wasps collected for each point in each type of vegetation. The number inside the bars indicates a total richness for each vegetation. Different capital letters represent significant differences. 
The three most abundant species at each study site were as follows: (1) regenerating Cerrado: Ag. pallipes, Polybia ignobilis (Haliday) and Ag. vicina, all from the Epiponini; (2) Cerradão: Ag. vicina, Ag. pallipes and M. rotundicollis; (3) semideciduous forest: Ag. vicina, Ag. pallipes, Agelaia multipicta (Haliday), the only area in which the three most abundant species all belonged to the genus Agelaia; (4) riparian forest: Ag. vicina, Ag. pallipes and Mischocyttarus drewseni (Saussure); (5) restored forest: M. montei, P. chrysothorax and M. rotundicollis (Table 2). The latter differs from the pattern observed in other areas, where Agelaia occupied at least two of the top three positions.

The highest species richness was found in riparian forest and regenerating Cerrado.

Regenerating Cerrado showed a marked difference between Ag. pallipes $(59.93 \%, \mathrm{n}=178)$ and P. ignobilis $(8.09 \%, \mathrm{n}=24)$. Agelaia vicina was predominant in three of the five areas but occupied the third position $(5.39 \%, \mathrm{n}=16)$ in regenerating Cerrado and the fifth position $(3.68 \%, \mathrm{n}=6)$ in restored forest. Agelaia vicina was the most abundant in Cerradão, semideciduous forest and riparian forest, followed by Ag. pallipes. The difference between these first two positions was not pronounced. Restored forest was the only area with different predominant species, including $M$. montei $(33.12 \%$, $\mathrm{n}=54)$ and $P$. chrysothorax $(25.15 \%, \mathrm{n}=41)($ Table 2$)$.

\section{Unique species}

Riparian forest had the largest number of unique species $(n=6)$. Regenerating Cerrado had two unique species, and semideciduous forest and Cerradão each had one unique species. Apoica gelida (Van der Vecht) was found only in semideciduous forest, and this is the first record of this species for São Paulo state. Restored forest was the only area of this study with no exclusive species (Table 2).

\section{Constancy of social wasp species}

Regenerating Cerrado had ten constant species, Cerradão had six, and restored forest had eight. Semideciduous forest had three constant species, and riparian forest had seven. Agelaia pallipes and Ag. vicina were constant in all five areas, while $A g$. multipicta was constant in two (semideciduous and riparian forest), and this was the most represented genus in the samples. The species that showed $100 \%$ constancy were $\mathrm{Ag}$. pallipes (riparian forest and regenerating Cerrado), $A g$. vicina (riparian forest), and Polybia dimidiata (Olivier) (regenerating Cerrado) (Table 3).

The rarefaction method allowed us to compare the number of species between communities in which abundance was not equal. Rarefaction was calculated for the expected number of species in each community using comparisons of values from all samples reaching a standard size, or comparisons based on smaller sample of fewer individuals (among all possible samples). Semideciduous forest and Cerradão did not differ significantly and did not reach the
Table 3. Constancy (C) of social wasp species in five study sites in São Paulo, Brazil, classified as follows: constant species (C $\geq 50 \%)$; accessory species $(25 \% \leq \mathrm{C}<50 \%)$; incidental species $(\mathrm{C}<25 \%)$. RC: Regenerating Cerrado; C: Cerradão; RTF: Restored forest; FSD: Semideciduous forest; RF: Riparian forest.

\begin{tabular}{|c|c|c|c|c|c|}
\hline \multirow[t]{2}{*}{ Species } & \multicolumn{5}{|c|}{$(\%)$ Constancy } \\
\hline & $\mathrm{RC}$ & $\mathrm{C}$ & RTF & FSD & $\mathrm{RF}$ \\
\hline Agelaia multipicta & 33.4 & 16.7 & 33.4 & 66.7 & 66.7 \\
\hline Agelaia pallipes & 100.0 & 83.4 & 83.4 & 50.0 & 100.0 \\
\hline Agelaia vicina & 50.0 & 50.0 & 66.7 & 83.4 & 100.0 \\
\hline Apoica gelida & - & - & - & 16.7 & - \\
\hline Apoica pallens & 33.4 & 16.7 & 33.4 & - & 33.4 \\
\hline Brachygastra lecheguana & - & - & - & - & 50.0 \\
\hline Polybia chrysothorax & 66.7 & 16.7 & 66.7 & - & 33.4 \\
\hline Polybia dimidiata & 100.0 & 50.0 & 16.7 & 33.4 & 66.7 \\
\hline Polybia fastidiosuscula & 50.0 & 66.7 & 33.4 & 16.7 & 83.3 \\
\hline Polybia ignobilis & 83.4 & 16.7 & - & - & 33.4 \\
\hline Polybia minarum & 16.7 & - & - & 16.7 & - \\
\hline Polybia occidentalis & 50.0 & 50.0 & - & - & 66.7 \\
\hline Polybia paulista & 33.4 & - & - & - & 16.7 \\
\hline Polybia sericea & 16.7 & - & - & - & - \\
\hline Polybia jurinei & 50.0 & 16.7 & 33.4 & 16.7 & - \\
\hline Protonectarina sylveirae & 16.7 & - & - & - & - \\
\hline Synoeca cyanea & 33.4 & 16.7 & - & - & 16.7 \\
\hline Mischocyttarus drewseni & 16.7 & - & 66.7 & 16.7 & 66.7 \\
\hline Mischocyttarus mattogrossensis & 66.7 & - & 33.4 & 16.7 & 16.7 \\
\hline Mischocyttarus rotundicollis & 66.7 & 83.4 & 83.3 & - & 16.7 \\
\hline Mischocyttarus paraguayensis & - & - & - & - & 16.7 \\
\hline Mischocyttarus ignotus & - & - & 33.4 & - & 16.7 \\
\hline Mischocyttarus tricolor & 33.4 & - & 50.0 & - & - \\
\hline Mischocyttarus montei & 33.4 & - & 66.7 & 16.7 & 16.7 \\
\hline Polistes cinerascens & - & - & - & - & 16.7 \\
\hline Polistes billardieri & - & 16.7 & - & - & - \\
\hline Polistes lanio & 83.4 & - & 50.0 & 33.4 & - \\
\hline Polistes simillimus & - & - & - & - & 16.7 \\
\hline Polistes geminatus & - & - & - & - & 16.7 \\
\hline Polistes subsericius & - & - & - & - & 33.4 \\
\hline Polistes versicolor & - & 33.4 & - & - & 16.7 \\
\hline
\end{tabular}

asymptote with the number of species collected. The restored forest differed from all other areas, but had the best slope of the curve. Regenerating Cerrado and riparian forest also differed from other areas, and did not stabilize with the number of species collected (Fig 4). However, species accumulation curves indicated that only riparian forest and Cerradão had new records in the last collections (Fig 3).

\section{Influence of environmental variables on social wasp distribution}

Mean weekly temperature correlated significantly $(p<$ 0.05 ) with weekly relative humidity and monthly temperature and precipitation. Also, monthly precipitation correlated 


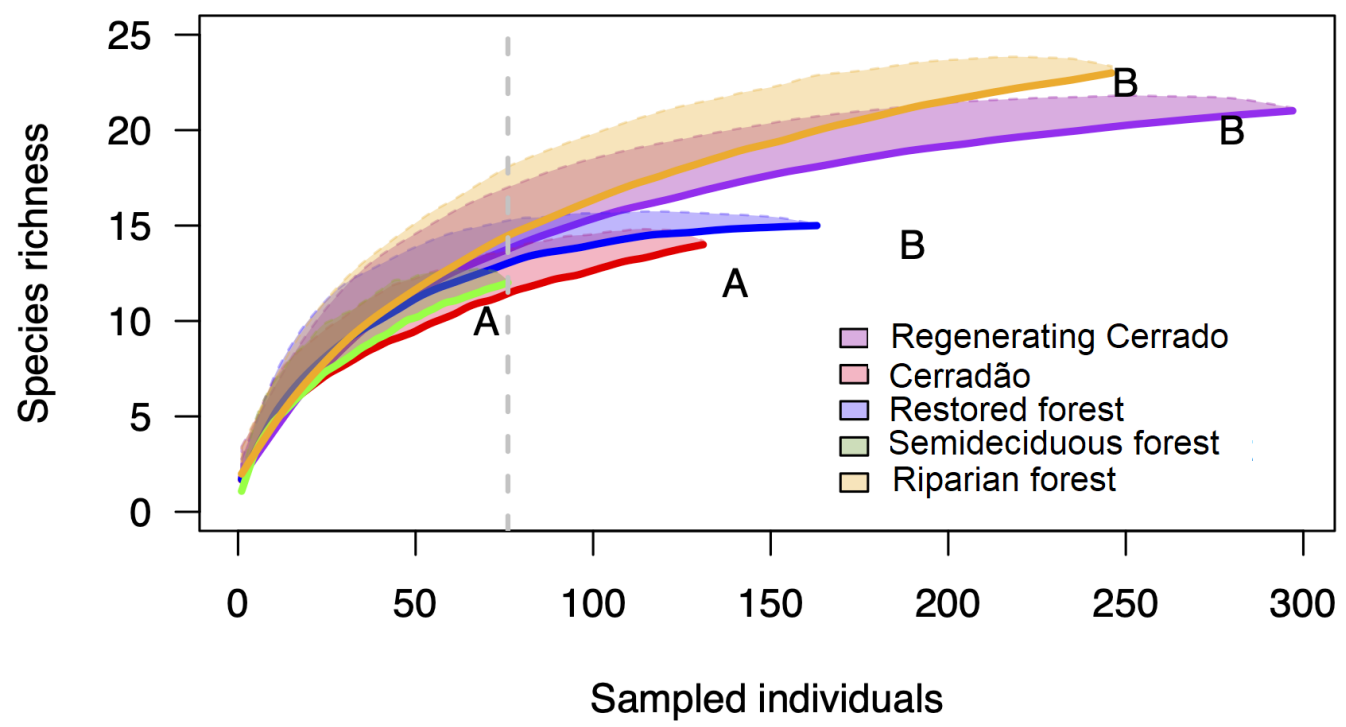

Fig 4. Rarefaction curves based on sampling. The curves with different letters indicate significant differences.

significantly with relative humidity and weekly temperature, and both estimates of relative humidity correlated between them. Because of that we fitted models only with monthly estimates of precipitation, mean temperature and relative humidity.

Overall, the interaction between rainfall and vegetation type had a significant effect on species richness $\left(\chi^{2}=10.37 ; d\right.$. $f .=4 ; p=0.0346$ ). Rainfall had no influence on the richness of social wasps in the different vegetation types but in the restored forest $(z=3.3, p=0.0056)$ where species richness increased with rainfall (Fig 6a). Neither monthly estimates of relative humidity and temperature affected species richness at any site $\left(\chi^{2}<8.2, d . f .=4, p>0.08\right)$.

Overall, the interaction between rainfall and vegetation type had a significant effect on the abundance of wasps, $\left(\chi^{2}=35.91 ; 4 ; d . f .=4 ; p<0.0001\right)$. However, while this interaction was positive in the restored forest $(z=4.94, p<$ 0.0001 ) for the Cerradão showed a negative association, i.e., less precipitation yielded more wasps $(z=2.98, p=0.0143)$ (Fig 6b).

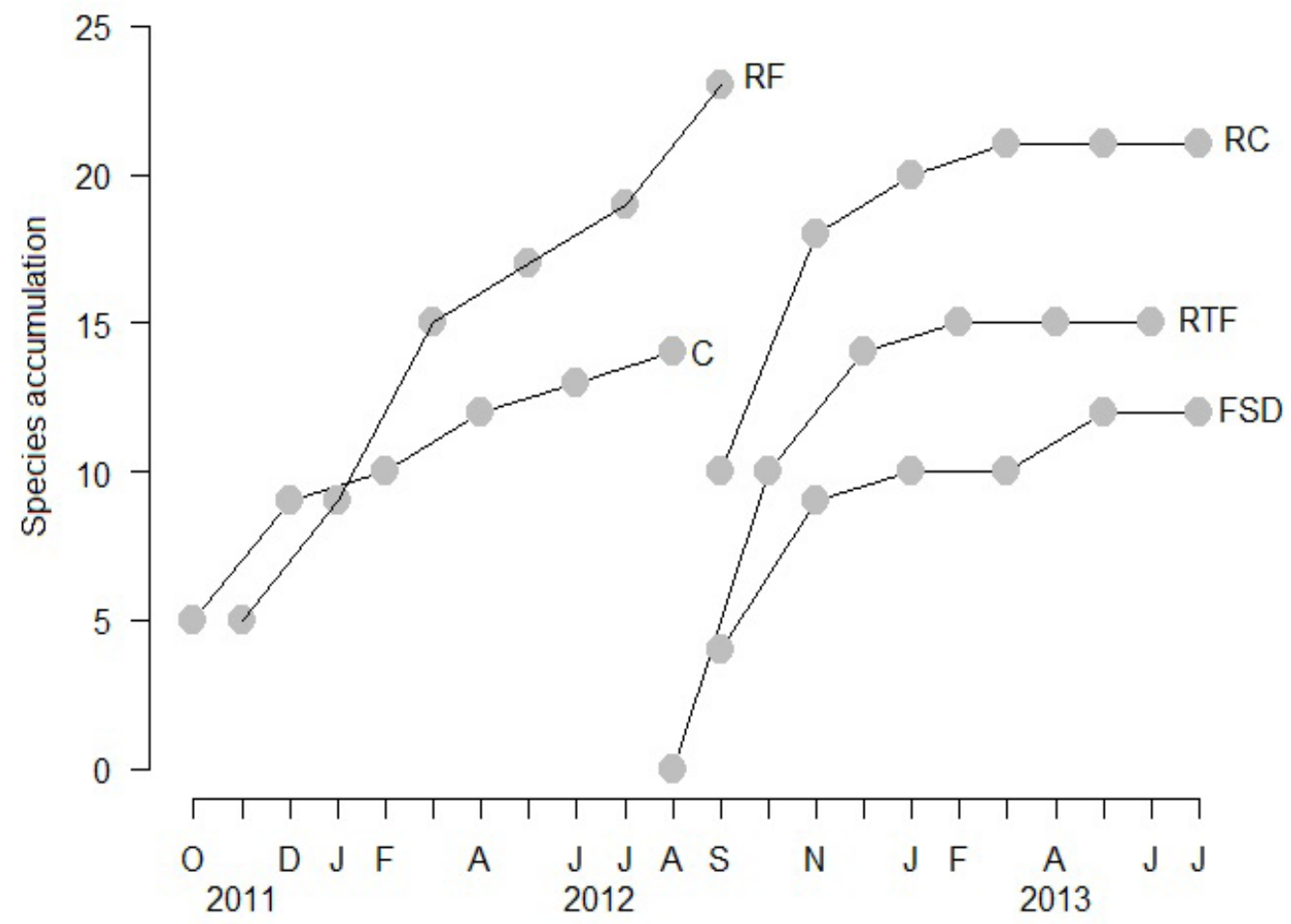

Fig 5. Rarefaction curves for each study area using different sampling methods from 2011 to 2013. RC: Regenerating Cerrado; C: Cerradão; RTF: Restored forest; FSD: Semideciduous forest; RF: Riparian forest. Letters at the right extreme of the curves indicate the homogenous groups at rarefied point. 
For the mean monthly temperature we found an overall significant effect $\left(\chi^{2}<38.5, d . f .=4, p<0.0001\right)$, and the post hoc contrast revealed that this effect was only significant at the restored forest $(z=6.91 ; p<0.0001)$ where abundance increased with temperature (Fig $6 \mathrm{c}$ ). For the monthly relative humidity we found no effects on wasp abundance $\left(\chi^{2}=7.79\right.$, d. $f .=4 ; p=0.0998$ ).

\section{Discussion}

Social wasp diversity in east-central São Paulo

Other studies have also found a predominance of Epiponini, representing on average over $70 \%$ of the total
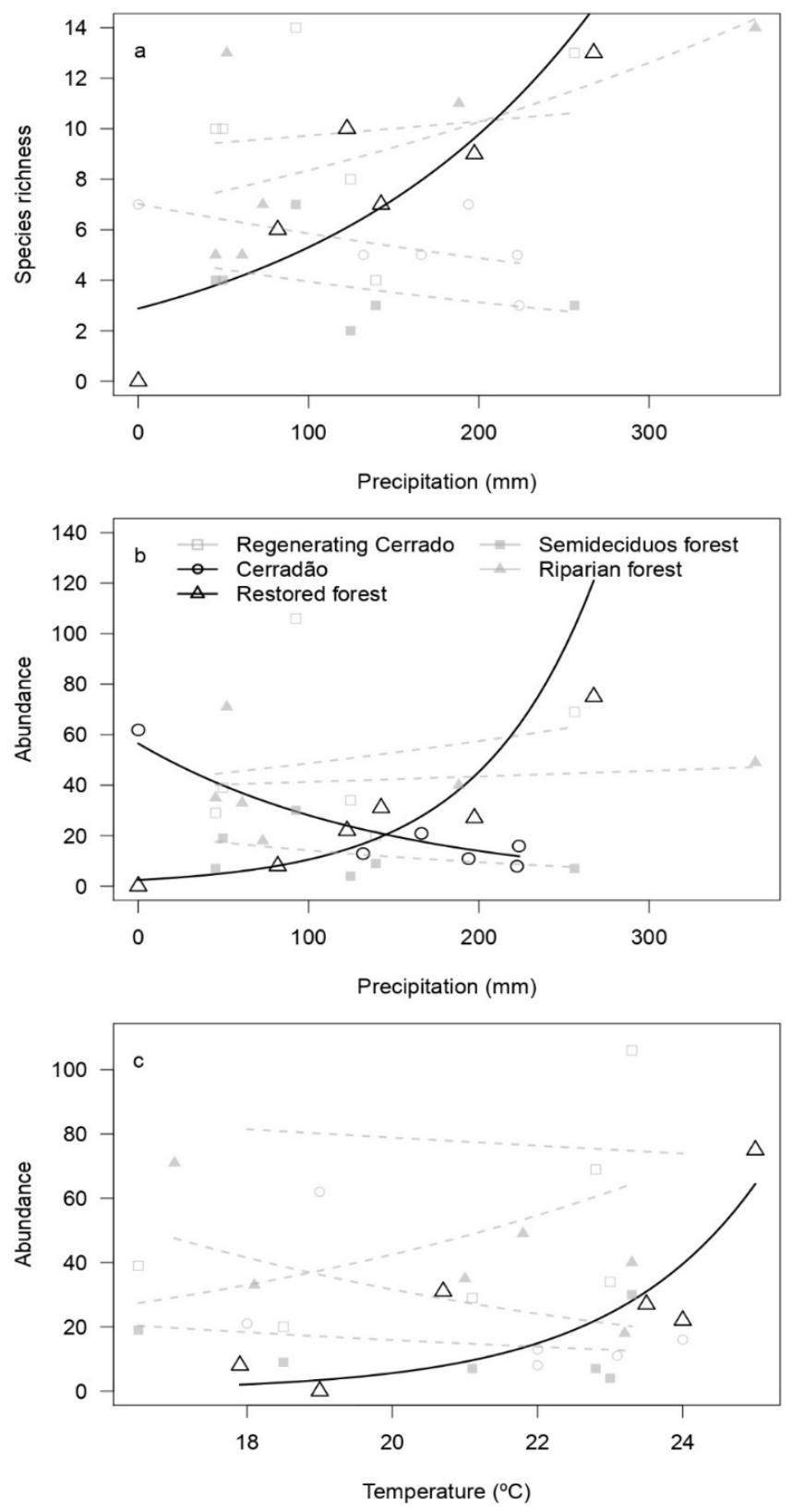

Fig 6. Effects of monthly precipitation on a) species richness and b) abundance, and effect of, c) mean temperature on the abundance of social wasp in five vegetation types in southern Brazil. Significant relationships are shown in black color, while no significant relationship are in grey color. individuals collected in different biomes and regions of Brazil (Santos, 1996; Gomes \& Noll, 2009; Pereira \& AntonialliJunior, 2011; Tanaka-Junior \& Noll, 2011). In contrast to the other two tribes that make up the subfamily Polistinae, Epiponini consists of swarming species that may have very large nests and thus, high abundance (Carpenter \& Marques, 2001). However, surveys only performed via searching for nests show a lower abundance of Epiponini, ranging between 11 and 68\% (Lima et al., 2000; Santos \& Presley, 2010; Santos et al., 2009.) This is probably due to the removal of Epiponini nests by humans because of their large size and destruction from rain.

All Agelaia species sampled in this study were present in all study sites. Agelaia vicina builds the largest nests among the Polistinae, in instance, Zucchi et al. (1995) reported an only one colony with more than a million adults and a nest with over 7.5 million brood cells. Oliveira et al. (2010) added that fast growth rates, large population sizes, and high numbers of queens contribute to the large nest sizes found in these species.

Polybia is a genus with 59 described valid species across 11 subgenera, with species ranges extending from the southern United States to northern Argentina (Richards, 1978; Carpenter \& Marques, 2001). This is typically one of the genera with the largest number of species collected in surveys and ecological studies (Richards, 1978; Carpenter \& Marques, 2001). Additionally, they are swarm founders with colonies that number in the hundreds or thousands of individuals (Carpenter \& Marques, 2001), which explains the high abundance found in this study.

Mischocyttarus species prefer nesting substrates associated with human construction (Lima et al., 2000), and are more synanthropic. Similar data were observed by Marques et al. (1993) in Cruz das Almas, Bahia, in northeastern Brazil. Social wasps build their nests in association with human-made structures likely because the urban environment reduces predation pressure and provides a greater range of environments for nest protection in bad weather, increasing success (Fowler, 1983; Ramos \& Diniz, 1993). The present study supports this notion, as the primary sample areas had a high degree of human disturbance. However, we did not count the number of colonies in the collection areas, since it was not the objective of the present study.

Wasp richness and abundance among study sites

Giannotti (1998) studied Mischocyttarus cerberus (Richards) biology in a reforested area of the Edmundo Navarro de Andrade State Forest, in Rio Claro, on the banks of a lake. He found six Mischocyttarus species in this area (M. cerberus, M. cassununga (Von Ihering), M. drewseni, M. araujoi (Zikán), M. socialis (Saussure) and another unidentified), as well as Polistes simillimus (Zikán), Ag. pallipes, Ag. multipicta and $P$. chrysothorax. A similar study of restored forest in Iracemápolis on the banks of a reservoir showed the predominance of Mischocyttarus over other Polistinae. 
Graham et al. (2009) found that ant richness may be higher in areas with an intermediate degree of human disturbance, as we found in the current study with wasps. However, similar results have not been found for other groups of insects (Didham et al., 1998; Nemésio \& Silveira, 2006).

In this work, the greatest wasp species richness was found in riparian forest and regenerating Cerrado (Fig 3). Other studies evaluating species richness over a range of physiognomies have also shown high wasp richness in riparian forests. In a riparian forest area in Batayporã, Mato Grosso do Sul, Pereira and Antonialli-Junior (2011) found 512 individuals belonging to 18 different species.

In our study, the riparian forest site is surrounded by a matrix of sugarcane crop, and the regenerating Cerrado consists of an array of Eucalyptus spp. and borders urban areas; these two crops are common in the region. Santos et al. (2009) suggested that although environments with arable systems have relatively homogeneous vegetation structure, there is a high availability of resources like nectar, prey, and water, and this, in turn, can support high social wasp species richness. Santos et al. (2007) demonstrated that environments with more complex vegetation structure enable the establishment and survival of a greater number of social wasp species. Vegetation structure directly affects social wasp communities by providing nesting substrate and food resources, and indirectly through variation in temperature, humidity, and ambient shadow. Species with specific nesting conditions select locations based on vegetation type and density, whether vegetation is open or closed, and by the shape and arrangement of leaves and other plant structures (Diniz \& Kitayama, 1994).

According to Rizzini (1963), canopy density in semideciduous forests varies according to the degree of disturbance. The arboreal component exists in two distinct floristic strata; one layer 7 to $15 \mathrm{~m}$ in height, and an upper canopy layer reaching 20 to $25 \mathrm{~m}$ (Pagano et al., 1987). This stratified canopy restricts light penetration to the forest understory, making active searching difficult due to low visibility. In the Atlantic forest fragment, canopy gaps formed by falling trees enabled active searching. However, much of the transect had low light because of the closed canopy, and this factor may have influenced the number of captures. A study with Synoeca cyanea (Fabricius) showed that the number of foraging individuals increases with light intensity (Elisei et al., 2005). Dense vegetation makes searching for individuals and colonies difficult, as they become cryptic in this type of environment (Wenzel \& Carpenter, 1994). The vegetational composition of semideciduous forest fragment makes search and collection of insects difficult, thus the wasp fauna was likely underestimated in this area.

Our data support results found by Souza and Prezoto (2006), showing lower species richness in semideciduous forest $(S=25)$ compared to Cerrado $(S=33)$. Silveira (2002) reported difficulty in capturing social wasps inside the Amazon forest, with effective capture only near the edges where near canopy gaps (as in this study). In areas of tall and dense vegetation active search for wasp nests is more difficult, and it is more difficult to achieve sufficient numbers of samples (Silveira, 2002).

The high species richness in regenerating Cerrado may be regarded areas with a high degree of human disturbance and human-made structures (such as buildings) can protect from predators and inclement weather, and thus may provide a higher probability of success (Ramos \& Diniz, 1993). However, Santos et al. (2007) found greater social wasp richness in Atlantic forest (18 species) than in restinga (16 species) and mangrove (eight species); this difference may be due to environmental conditions (salinity, temperature, and dryness) in areas with lower richness.

Agelaia pallipes was most abundant in regenerating Cerrado, accounting for approximately $60 \%$ of all individuals collected using both sampling methods (Table 2). This result is supported by other studies (Gomes \& Noll, 2009). Agelaia pallipes is less sensitive to environmental degradation, which may explain its high abundance in regenerating Cerrado (i.e., an area with a high degree of degradation). Agelaia vicina was more common in better preserved areas because they utilize hollow tree trunks or large natural cavities such as caves to accommodate their large colonies (Zucchi et al., 1995; Oliveira et al., 2010). A study conducted in four cities in northwestern São Paulo found this species in all areas (Tanaka-Junior \& Noll, 2011), and this trend is supported other studies such as Gomes and Noll (2009).

\section{Unique species}

Santos et al. (2007) reported a positive correlation between environmental structural complexity and establishment and survival of many social wasp species. Because riparian forest has high availability of habitats and resources, it is expected to support a higher number of unique species compared to other vegetation types in the study.

\section{Constancy of social wasp species}

Wasps from the Epiponini tribe are known to form new colonies through swarming, in which nests are built by a group of workers who are accompanied by one or more queens (Jeanne, 1980). Because of this it is possible to find species from this tribe in every month of the year.

\section{Influence of environmental variables on social wasp distribution}

In Mata do Baú, a cerrado fragment in Barroso municipality, Minas Gerais, Souza et al. (2014) found a positive correlation between species richness and rainfall indices (as found in restored forest in the current study). The higher species richness found in wetter periods does not indicate increased foraging activity under these conditions, but may indicate better environmental conditions for species to merge colonies, as verified by the same work by Souza et al. 
(2014) and also by studies carried out in caatinga (a tropical dry forest found exclusively in Brazil) (Santos et al., 2009).

Only restored forest showed a correlation between temperature and social wasp species richness and abundance. Togni et al. (2014) also failed to establish such relationships, however, a correlation between humidity and richness was found in this study, in Ubatuba, São Paulo. Wasp richness and abundance was greater in the hot-humid season, as a greater number of species are influenced by rainfall $(\mathrm{mm})$ in the rainy season. These characteristics favor an increase in plant biomass, which provides more nest substrate and a greater supply of food resources like flower nectar and insect herbivores, especially caterpillars (i.e., the main prey of social wasps) (Prezoto, 1999). Similar trends have been found by other authors (Diniz \& Kitayama, 1994; Souza \& Prezoto, 2006).

\section{Conclusion}

We conclude that richness and diversity of social wasps are affected in different ways, such as: degree of anthropogenic disturbance, characteristics of vegetation and to a lesser extent by precipitation. These effects are probably mediated by the resulting differences in the provision of resources and nesting sites between different environments. The areas of this study suffered considerable loss of vegetation due to common agricultural practices, however, the existing fragments are still capable of hosting a rich fauna of social wasps.

\section{Acknowledgements}

This work received financial support from the Education Personnel Improvement Coordination (CAPES) and National Council for Scientific and Technological Development $(\mathrm{CNPq})$. We thank the Mexican Institute of Ecology (INECOL) for partnership.

\section{Authors' contributions}

Mateus Aparecido Clemente - Lead author and responsible for all phases of this study.

Roger Guevara - Conducting statistical analyzes.

Hugo Ribeiro Moleiro - Collaborated in the collections.

Orlando Tobias Silveira-Taxonomist responsible for correcting identifications.

Edilberto Giannotti - Responsible advisor.

\section{References}

Andena, S.R. \& Carpenter, J.M. (2014). Checklist das espécies de Polistinae (Hymenoptera, Vespidae) do semiárido brasileiro. In: F. Bravo \& A. Calor (Eds.), Artrópodes do Semiárido: Biodiversidade e Conservação (pp. 169-180). Feira de Santana: Editora Printmídia.

Ayres, M., Ayres Junior, M., Ayres, D.L. \& Santos, A.A. (2007). BioEstat - Aplicações estatísticas nas áreas das ciências bio-médicas. Belém: ONG Mamirauá, 364 p.
Barbosa B.C., Detoni M., Maciel T.T. \& Prezoto F. (2016). Studies of social wasp diversity in Brazil: Over 30 years of research, advancements and priorities. Sociobiology, 63: 858880. doi: 10.13102/sociobiology.v63i3.1031

Bates, D., Maechler, M., Bolker, B. \& Walker, S. (2015). Fitting Linear Mixed-Effects Models Using lme4. Journal of Statistical Software, 67: 1-48.

Bodenheimer, F.S. (1955). Précis D'écologie Animale. Paris: Payot, $315 \mathrm{p}$.

Cardoso-Leite, E., Covre, T.B., Ometto, R.G., Cavalcanti, D.C. \& Pagani, M.I. (2004). Fitossociologia e caracterização sucessional de um fragmento de Mata Ciliar, em Rio Claro, SP, como subsídio à recuperação da área. Revista do Instituto Florestal, 16: 31-41.

Carpenter, J.M \& Marques, O.M. (2001). Contribuição ao estudo dos vespídeos do Brasil (Insecta, Hymenoptera, Vespoidae), Vol. 2. Cruz das Almas: Universidade Federal da Bahia - Série Publicações Digitais, 147 p.

Clemente, M.A., Lange, D., Del-Claro, K., Prezoto, F., Campos, N.R. \& Barbosa, B.C. (2012). Flower-visiting social wasps and plants interaction: network pattern and environmental complexity. Psyche, 1-10. doi: 10.1155/2012/478431.

Cruz, J.D., Giannotti, E., Santos, G.M.M., Bichara-Filho, C.C. $\&$ Rocha, A.A. (2006). Nest site selection and flying capacity of neotropical wasp Angiopolybia pallens (Hymenoptera: Vespidae) in the Atlantic Rain Forest, Bahia State. Sociobiology, 47: 739-749.

Didham, R.K., Hammond, P.M., Lawton, J.H., Eggleton, P. \& Stork, N.E. (1998). Beetle species responses to tropical forest fragmentation. Ecological Monographs, 68: 295-323. doi: 10.1890/0012-9615(1998)068[0295: BSRTTF]2.0.CO;2.

Diniz, I.R. \& Kitayama, K. (1994). Colony densities and preferences for nest habitats of some social wasps in Mato Grosso State, Brazil (Hymenoptera: Vespidae). Journal of Hymenoptera Research, 3: 133-143.

Elisei, T., Guimarães, D.L., Ribeiro-Junior, C. \& Prezoto, F. (2005). Foraging activity and nesting of swarm-founding wasps Synoeca cyanea (Hymenoptera: Vespidae, Polistinae). Sociobiology, 46: 317-322.

Fowler, H.G. (1983). Human effects on nest survivorship of urban synanthropic wasps. Urban Ecology, 7: 137-143. doi: 10.1016/0304-4009(83)90032-3

Giannotti, E. (1998). The colony cycle of the social wasp, Mischocyttarus cerberus styx Richards, 1940 (Hymenoptera, Vespidae). Revista Brasileira de Entomologia, 41: 217-224.

Gomes, B. \& Noll, F.B. (2009). Diversity of social wasps (Hymenoptera, Vespidae, Polistinae) in three fragments of semideciduous seasonal forest in the northwest of São Paulo State, Brazil. Revista Brasileira de Entomologia, 53: 428-431. 
doi: $10.1590 / \mathrm{S} 0085-56262009000300018$.

Graham, J.H., Krzysik, A.J., Kovacic, D.A., Duda, J.J., Freeman, D.C., Emlen, J.M., Zak, J.C., Long, W.R., Wallace, M.P., Chamberlin-Graham, C., Nutter, J.P. \& Halbach, H.E. (2009). Species richness, equitability, and abundance of ants in disturbed landscapes. Ecological Indicators, 9: 866-877. doi: 10.1016/j.ecolind.2008.10.003.

Hammer, Ø., Harper, D.A.T. \& Ryan, P.D. (2001). PAST: Paleontological Statistics software package for education and data analysis. Palaeontologia Eletronica, 4: $9 \mathrm{p}$. Retrieved from: https://s3.amazonaws.com/academia.edu. documents/39675641/PAST_Paleontological_Statistics_ Software...Signature $=\mathrm{b} 31709 \mathrm{efc} 6 \mathrm{f} 92 \mathrm{fb} 8 \mathrm{bc0e} 4 \mathrm{e} 343 \mathrm{e} 930 \mathrm{c} 38 \mathrm{c}$ 496fdd1ea8a76c3887cfcce29560828.

Jeanne, R. L. 1980. Evolution of social behavior in the Vespidae. Annual Review of Entomology, 25: 371-395.

Krebs, C.J. (1998). Ecological Methodology. $2^{\text {nd }}$. ed. New York: Addison Wesley Longman, $620 \mathrm{p}$.

Lima, M.A.P., Lima, J.R. \& Prezoto, F. (2000). Levantamento dos gêneros de vespas sociais (Hymenoptera, Vespidae), flutuação das colônias e hábitos de nidificação no campus da UFJF, Juiz de Fora, MG. Revista Brasileira de Zoociências, 2: 69-80.

Locher, G.A., Togni, O.C., Silveira, O.T., Giannotti, E. (2014). The social wasp fauna of a riparian forest in southeastern Brazil (Hymenoptera, Vespidae). Sociobiology, 61: 225-233. doi: 10.13102/sociobiology.v61i2.225-233.

Marques, O.M., Carvalho, C.A.L. \& Costa, J.M. (1993). Levantamento das espécies de vespas sociais (Hymenoptera: Vespidae) no município de Cruz das Almas - Estado da Bahia. Insecta, 2: 1-9.

Nemésio, A. \& Silveira, F.A. (2006). Edge Effects on the Orchid-Bee Fauna (Hymenoptera: Apidae) at a Large Remnant of Atlantic Rain Forest in Southeastern Brazil. Neotropical Entomology, 35: 313-323. doi: 10.1590/S1519-566X 2006000300004.

Oliveira, O.A.L.D., Noll, F.B. \& Wenzel, J.W. (2010). Foraging behavior and colony cycle of Agelaia vicina (Hymenoptera: Vespidae; Epiponini). Journal of Hymenoptera Research, 19: 4-11.

Pagano, S.N. \& Leitão Filho, H.F. (1987). Composição florística do estrato arbóreo de mata mesófila semidecídua no município de Rio Claro (estado de São Paulo). Revista Brasileira de Botânica, 10: 34-47.

Pagano, S.N., Leitão Filho, H.F. \& Shepherd, G.J. (1987). Estudo fitossociológico em mata mesófila semidecídua no município de Rio Claro (Estado de São Paulo). Revista Brasileira de Botânica, 10: 49-61.

Pereira, M.G.C. \& Antonialli-Junior, W.F. (2011). Social wasps in riparian forest in Batayporã, Mato Grosso do Sul
State, Brazil. Sociobiology, 57: 153-163. doi: 10.13102/ sociobiology.v59i3.545.

Pickett, K.M. \& Wenzel, J.W. (2007). Revision and cladistic analysis of the nocturnal social wasp genus, Apoica Lepeletier (Hymenoptera: Vespidae; Polistinae, Epiponini). American Museum Novitates, 3562: 1-30. doi: 10. 1206/00030082(2007)397[1:RACAOT]2.0.CO;2

Pinheiro, J.C., Bates, D.J., DebRoy, S. \& Sakar, D. (2012). The Nlme package: linear and non-linear mixed effects models, $\mathrm{R}$ Version 3. R Package Version 3.1-103. Retrieved from: https://cran.r-project.org/web/packages/nlme/.

Prezoto, F. (1999). A importância das vespas como agentes no controle biológico de pragas. Biotecnologia, Ciência \& Desenvolvimento, 2: 24-26.

Ramos, F. \& Diniz, I.R. (1993). Seasonal cycles, survivorship and growth of colonies of Polistes versicolor in an urban area of Brasília. The Entomologist, 112: 191-200.

R Development Core Team - A language and environment for statistical computing. (2012). R Foundation for Statistical Computing, Vienna. Retrieved from: http://www.r-project.org.

Richards, O.W. (1978). The social Wasps of the Americas, Excluding the Vespinae. London: Natural History Museum, 580 p.

Rizzini, C.T. (1963). A flora do cerrado, análise florística das savanas centrais. In M.G. Ferri, Simpósio Sobre o Cerrado (pp. 126-177). São Paulo: Editora da Universidade de São Paulo/Editora Edgaard Blücher.

Sanders, H.L. (1968). Marine benthic diversity: a comparative study. American Naturalist, 102(925): 243-282. doi: 10.1086/282541.

Santos, B.B. (1996). Ocorrência de vespideos sociais (Hym., Vespidae) em pomar em Goiânia, Goiás, Brasil. Revista do Setor de Ciências Agrárias, 15: 43-46.

Santos, G.M.M., Bichara, F.C.C., Resende, J.J., Cruz, J.D. \& Marques, O.M. (2007). Diversity and community structure of social wasps (Hymenoptera: Vespidae) in three ecosystems in Itaparica Island, Bahia State, Brazil. Neotropical Entomology, 36: 180-185. doi: 10.1590/S1519-566X2007000 200002.

Santos, G.M.M., Bispo, P.C. \& Aguiar, C.M.L. (2009). Fluctuations in richness and abundance of social wasps during the dry and wet seasons in three phytophysiognomies at the tropical dry forest of Brazil. Environmental Entomology, 38: 1613-1617. doi: 10.1603/022.038.0613.

Santos, G.M.M. \& Presley, S.J. (2010). Niche Overlap and Temporal Activity Patterns of Social Wasps (Hymenoptera: Vespidae) in a Brazilian Cashew Orchard. Sociobiology, 56: 121-131.

Setzer, J. (1966). Atlas Climático e Ecológico do Estado de São Paulo. São Paulo: CESP/Comissão Interstadual da Bacia Paraná-Uruguai, $61 \mathrm{p}$. 
Silveira, O.T. (2002). Surveying Neotropical social wasps. An evaluation of methods in the "Ferreira Penna" Research station (ECFPn), in Caxiuanã, PA, Brazil (HYM., Vespidae, Polistinae). Papéis Avulsos de Zoologia, 42: 299-323. doi: 10.1590/S0031-10492002001200001.

Silveira Neto, S., Nakano, O., Barbin, D. \& Nova, N.A.V. (1976). Manual de Ecologia dos Insetos. São Paulo: Editora Agronômica Ceres, 419 p.

Silveira, H.L.F., Vettorazzi, C.A. \& Valente, R.O.A (2008). Avaliação multicriterial no mapeamento de risco de incêndios florestais, em ambiente sig, na bacia do Rio Corumbataí, SP. Revista Árvore. 32, 259-268. doi: 10.1590/S0100-67622 008000200009

Souza, M.M., Pires, E.P. \& Prezoto, F. (2014). Seasonal richness and composition of social wasps (Hymenoptera, Vespidae) in areas of cerrado biome in Barroso, Minas Gerais, Brazil. Bioscience Journal, 30: 539-545.

Souza, M.M. \& Prezoto, F. (2006). Diversity of social wasps (Hymenoptera: Vespidae) in semideciduous forest and cerrado (Savanna) regions in Brazil. Sociobiology, 47: 135-147.

Tanaka-Junior, G.M. \& Noll, F.B. (2011). Diversity of Social Wasps on Semideciduous Seasonal Forest Fragments with Different Surrounding Matrix in Brazil. Psyche, 1-8. doi: $10.1155 / 2011 / 861747$.
Togni, O.C., Locher, G.A., Giannotti, E. \& Silveira, O.T. (2014). The social wasp community (Hymenoptera, Vespidae) in an area of Atlantic Forest, Ubatuba, Brazil. CheckList, 10: 1017. doi: 10.15560/10.1.10.

Vieira, D.C.M \& Gandolfi, S. (2006). Chuva de sementes e regeneração natural sob três espécies arbóreas em uma floresta em processo de restauração. Revista Brasileira de Botânica, 29: 541-554.

Warnes, G.R., Bolker, B., Lumley, T. \& Johnson, R.C. (2018). gmodels: Various R Programming Tools for Model Fitting. R package version 2.18.1. Retrieved from: https://cran.r-project. org/package $=$ gmodels.

Wenzel, J.W. \& Carpenter, J.M. (1994). Comparing methods, adaptative traits and tests of adaptation. In P. Eggleton \& R. Vane-Wright (Eds.), Phylogenetics and ecology (pp. 79-101). London: Academic Press.

Zucchi, R., Sakagami, S.F., Noll, F.B., Mechi, M.R., Mateus, S., Baio, M.V. \& Shima, S.N. (1995). Agelaia vicina, a swarmfounding Polistinae with the largest colony size among wasps and bees (Hymenoptera: Vespidae). Journal of the New York Entomological Society, 103: 129-137.

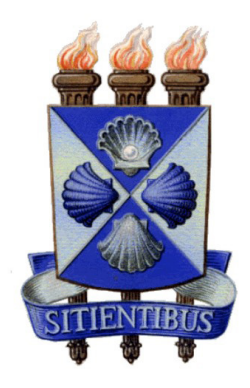

